\title{
The Musical Theater in Kraków and Lviv around 1900: Social Functions and Cultural Meanings ${ }^{1}$
}

\author{
Renata SuchowiEJKo \\ Institute of Musicology, Faculty of History \\ Jagiellonian University \\ ul. Westerplatte 10, 31033 Kraków, Poland \\ E-mail: renata.suchowiejko@uj.edu.pl
}

(Received: June 2017; accepted: September 2017)

\begin{abstract}
At the turn of the nineteenth and twentieth centuries, Kraków was a flourishing city, both economically and artistically. During the period of Galician autonomy, Kraków was granted significantly greater political freedom than other Polish cities located in the Prussian or Russian partitions. For this reason it became an important center for cultivating national tradition. Lviv, as the capital of the Crownland of Galicia and Lodomeria, was one of the most important centers of scholarship, education, and culture in this region. The city was a multi-ethnic, multi-cultural, and multilingual conglomerate of Poles, Ukrainians, Jews, and Ruthenians. Lviv's significance as an operatic center grew from the time when the German theater was closed in 1872 and a permanent Polish stage was created. This was a decisive moment for the development of the national opera, and Lviv became the main rival to Warsaw. The aim of this article is to present a general overview of the functioning of musical theater in Kraków and in Lviv, the two musical centers of Galicia. These cities were closely linked by institutional, artistic, cultural, and social bonds. In the artistic life a crucial part was played by the directors of the two city theaters, Tadeusz Pawlikowski and Ludwik Heller. Both made important contributions to the development of the opera.
\end{abstract}

Keywords: Galician autonomy, Kraków, Lviv, musical theaters, cultural transfers

At the turn of the nineteenth and twentieth centuries, musical culture developed vividly in Kraków and Lviv, ${ }^{2}$ the two main music centres in Galicia, permeating

1. A study carried out with support from the Visegrad Grants 2017-2018 for the project Musical Theater Companies in Multilingual East-Central Europe (21720187).

2. "Lwów" in Polish, "Lemberg" in German, "Львів" in Ukrainian, belonged during the interwar period to the territory of Second Republic of Poland, after the German-Soviet invasion of Poland in 1939 it became 
everyday life and inspiring the social activity of local communities. Not only did various choirs and musical societies develop their activities, but many other educational, charity, sport or entertainment social organizations and bodies also acted as the animators of musical culture. We can observe the fascinating process of a unique and exceptional cross-cultural musical dialogue. Around 1900 the two cities were flourishing and linked by strong institutional, cultural, and economic bonds. One might say that they formed a single organism, particularly in the areas of scholarship, culture, and art. Opera is the best example of this creative coexistence.

However, before we reach that point in the story, we must go back in time to outline the wider historical context of the region. The development of musical culture in Poland was highly dependent on the socio-political situation in which the country found itself in the nineteenth century. The turbulent political history created entirely different conditions from other European countries.

\section{Europe with and without Poland 1795-1918}

Poland lost independence in 1795, when its territory was annexed by Russia, Prussia, and Austria. The annexation which took place in three stages (in 1772, 1793, and 1795) was an unprecedented event in the history of modern Europe. Politics of expansion were not a new phenomenon, and the victors always divided the spoils among themselves. However, total annihilation of a substantial historical country in the center of Europe was an extraordinary event. The old Commonwealth of Both Nations, which covered an area similar to today's France or Spain, inhabited by 11 million people, ceased to exist. ${ }^{3}$

This was the result of a prolonged process, aimed at creating a new balance of power in Europe. In the second half of the eighteenth century, Poland had descended into political chaos and struggled with numerous internal problems. Attempts were made to solve them through reforms, but introducing order in Poland was against the interests of its powerful neighbors. Thus, they fueled Poland's internal conflicts and conducted their own game. Frederick the Great, Catherine the Second, and Maria Theresa acted in full accord, looking after their own interests. Russia was pressing towards the west, in order to "enter Europe" as far as possible. Prussia needed new lands in order to expand her territory and unite the scattered settlements in the north, while Austria could not remain a bystander in this political game.

part of the Soviet Union, in 1991 it was annexed to the independent state of Ukraine. It is the largest city in the western part of the country.

3. See Norman Davies, "Agonia. The End of the Russian Protectorate 1764-1795," in God's Playground: A History of Poland, vol. 1. The Origins to 1795 (New York: Columbia University Press, revised edition 2005). 
The greatest beneficiary of this game was Russia. As a result of the three partitions Russia occupied about $62 \%$ of the land which had belonged to Poland $\left(471,000 \mathrm{~km}^{2}\right)$, inhabited by $45 \%$ of the population (about 6 million people). Prussia occupied about $20 \%$ of the land $\left(148,000 \mathrm{~km}^{2}\right)$, with $23 \%$ of the population (2.7 million people). For the Hohenzollern monarchy this was a considerable gain, since it increased its territory by nearly a half. Austria gained relatively little land, $18 \%\left(129,000 \mathrm{~km}^{2}\right)$, but it was densely populated (3.8 million people). ${ }^{4}$

Outlining the general historical background is important, since it gives us a better understanding of some of the long-term cultural phenomena. The fallout of grand politics always had an influence on culture, both in its institutional and social aspects. The history of Polish musical culture provides excellent evidence of this. Moreover, the experience of partitions is so deeply ingrained in the cultural memory of Poles that its effects can still be felt today.

The aims and priorities of the partitioning powers were different, but their general strategy was very similar - that of rapid, enforced assimilation through legal, economic, and administrative mechanisms. The partitioned territories were fully subordinated to the central institutions in St Petersburg, Berlin, and Vienna, respectively. The official language was German or Russian and the same applied to education. This was enforced very strictly, particularly in the Russian and Prussian partitions. The policy of repression was very vigorous to start with, and increased after every national uprising. The infrastructure of musical life was undeveloped due to the unfavorable economic conditions along with the political decisions of the occupying empires suppressing local initiatives, especially in the periods of repressions after uprisings. With only few big concert halls and no permanent orchestras, the development of symphonic genres had been inhibited until the turn of the nineteenth and twentieth centuries when the situation became better.

The Poles did not accept the loss of independence and kept making attempts to regain it. The Congress of Vienna in 1815 brought a new distribution of power. A Congress Kingdom of Poland was created which, while linked to Russia by personal union with the Tsar, allowed the Poles a little more freedom. However, aspirations towards independence did not weaken and a number of uprisings followed. The most important of these were the November uprising of 1830 and the January uprising of 1863 . Each of them was followed by intensified repressions within the country and a wave of emigration abroad, mainly to France.

The uprisings were an important factor in building national identity; they shaped the consciousness of the Poles, strengthening the feeling of community and self-worth. In the collective memory and artistic imagination they underwent mythicalization and idealization. The topos of the fighting Poland, the suffering

4. See Jan Skarbek, "Europe With and Without Poland," in Poland. A History, eds. Jerzy Kłoczowski and Hubert Łaszkiewicz (Lublin: Institute of East-Central Europe, 2011). 
nation and the necessity of striving for freedom were given numerous representations in the literature and art of the nineteenth century.

Poland was removed from the political map of Europe in 1795 and did not exist as an independent state until 1918. But Polish people had never ceased to struggle to preserve their own national identity. A nation without state, i.e. people deprived of virtually any political instruments to make decisions of and for themselves, developed specific forms for the defense and protection of their historic memory and tradition, anchored in culture and art as their main way of expression.

\section{Galician Autonomy}

During the 1860s the situation in Europe underwent a fundamental change. In 1866 Prussia defeated Austria, four years later was victorious in the war with France, the Second Empire was proclaimed in 1871. However, the Polish question still remained the "glue" holding the powers together. After the fall of the January uprising, repressions in the Russian partition intensified significantly. Tsar Alexander II meted out brutal treatment to the insurrectionists - death sentences, prison, exile to Siberia, confiscation of property. Under Bismarck the policy of Germanization in the Prussian partition was applied very strictly. A number of repression tools were employed in the educational, administrative, and legal institutions.

In this context the situation in the Austrian partition appeared much better, particularly when Galicia was given autonomy. It became an almost independent province, subordinate to the central authority in Vienna, but with its own "Sejm" (Parliament of the Land) with its seat in Lviv and with extensive powers of self-determination. Political power was placed (mainly) in the hands of the Poles. Many of them held important posts in the government in Vienna. This was a period of relative stability, which facilitated the development of culture and art. Polish was restored as the language of education and in the administration system. The numbers of students increased considerably. In Kraków the Polish Academy of Arts and Sciences was established, which became the most important academic institution in the country. Societies, museums, publishing houses, theaters, and the press - all of these created a vibrant intellectual market which radiated its influence throughout the country. ${ }^{5}$

However, this beautiful picture of Galicia is only one of its faces. The autonomy stabilized the internal situation, but the internal conflicts did not diminish. The ethnic make-up of Galicia was very complicated. The majority of the pop-

5. See Andrzej Chwalba, "Zabór austriacki (Galicja) 1850-1914” [Austrian Partition (Galicia) 18501914], in Historia Polski 1875-1918 [History of Poland 1875-1918] (Kraków: Wydawnictwo Literackie, 2000). 
ulation was Polish, but alongside them lived Ukrainians, Jews, and Ruthenians. Each of these groups had its aims and aspirations, and this caused never-ending quarrels and conflicts. Galicia was an economically backward land, one of the poorest in the Austro-Hungarian monarchy. This resulted in, among other things, mass economic emigration. There was a permanent political argument between supporters of the imperial authority and nationalists. There was a growing Polish-Ukrainian conflict, which erupted with increased intensity immediately after the First World War.

Galicia no longer exists: it disappeared from the map of Europe in 1918. But it still exists in the consciousness and the collective memory of today's inhabitants of that region and those who emigrated out of Galicia. This is an imaginary space, with which Polish people feel an emotional and psychological bond. The myth of Galicia continues to shape their identity.

As Larry Wolff demonstrates in his remarkable book on the "idea of Galicia," this small province of the Habsburg monarchy that existed for a limited historical period became a place that continues to exercise a powerful fascination until today. The idea survived in consciousness and cultural memory even after the seat disappeared from the map of Europe. This sense of identity with the province was particularly strong among Jewish Galicians.

Galicia was created in 1772 at the historical moment of the first partition of Poland, when the Habsburg monarchy applied that name to Vienna's territorial portion of the partitions and conceived of Galicia as a new Habsburg Province. ... The population of the province included Poles, Ruthenians (today Ukrainians), Germans (including Austrians), and Jews. Galicia, invented in 1772, enjoyed a historical existence of less than a century and a half, from 1772 to the end of World War I and the abolition of the Habsburg monarchy in 1918. Galicia was then removed from the map of Europe, and today, almost a century later it belongs to the category of extinct geopolitical entities.

The territory of the former Galicia now lies divided between contemporary Poland and Ukraine, and, although the Galician Jews were almost entirely annihilated in the Holocaust during World War II, the earlier emigration of Galician Jews meant that they survived outside Galicia, especially in America and Israel, where they continued to identify themselves as "Galitzianer" long after leaving Europe and well into the twentieth century. ${ }^{6}$

Galicia is today a lieu de mémoire having special significance related to group's remembrance. Its myth is still alive and maintains its influential role.

6. Larry Wolff, The Idea of Galicia. History and Fantasy in Habsburg Political Culture (Stanford: Stanford University Press, 2010), 1. 
Galicia is a territory where memories meet: memories of Poles, Ukrainians, Austrians, Jews, but also Czechs, Hungarians, and Armenians. On top of that, the memory of a "paradise lost" is today exterritorial. We find it not only on both sides of the San River, in Lviv and Kraków, but also, for example, in Wrocław and Vienna, in Jerusalem and Haifa, and in Brooklyn and California. The mass emigration of two million Galicians in the 19th/20th century to the United States certainly contributed to the internationalisation and spreading of Galician mythology. ... Galicia after Galicia is the phenomenon of diversity, which today denotes polyphony of memory dominated by myths. ${ }^{7}$

\section{Kraków: the city of Mtoda Polska [Young Poland]}

At the turn of the nineteenth and twentieth centuries, Kraków became the main center of the Młoda Polska [Young Poland], a powerful movement of artistic renewal which encompassed all the aspects of artistic life. The city was "boiling over" with creative energy. The newly-opened Municipal Theater (1893, see Plate 1) staged plays by Henrik Ibsen, Maurice Maeterlinck, Gerhart Hauptmann, and Stanisław Wyspiański. The newly-created Society of Polish Artists Sztuka (1897) helped young artists, like Jacek Malczewski, Józef Mehoffer, and Teodor Axentowicz to enter artistic life. Much ferment was introduced into the artistic life of the city by Stanisław Przybyszewski, the main scandal-maker and ideologue of Young Poland.

At the same time Kraków was deeply rooted in tradition and looked towards the past. It was surrounded by an almost mythical aura, a living monument of the Polish tradition. As the former capital of Poland with its Royal Castle and the Royal Necropolis, hosting the second oldest university in this part of Europe, was the focal point of all Polish people. Kraków became the symbol of Polish identity and virtues, the anchor of Polish tradition and a place where patriotic manifestations were held. In spite of the atmosphere being favorable to the arts, not every branch could fully develop. Musical theater did not have institutional support: in Kraków there was no permanent operatic stage. ${ }^{8}$

7. Jacek Purchla, "Galicia after Galicia, or: On the Uniqueness of the Myth of the "Vanished Kingdom,", in The Myth of Galicia, eds. Jacek Purchla, Wolfgang Kos, et alia (Kraków: International Cultural Centre, 2014), 88, 90 .

8. On the musical life in Kraków at the turn of the centuries see Renata Suchowiejko, "Kraków around 1900 - a Musical Panorama of the Town," in Musik - Stadt. Traditionen und Perspektiven urbaner Musikkulturen, Bd. 1: Traditionen städtischer Musikgeschichte in Mittel- und Osteuropa, hrsg. Helmut Loos (Leipzig: Gudrun Schröder Verlag, 2011), 102-109. 
Plate 1 Postcard depicting the Municipal Theater in Kraków ca. 1900

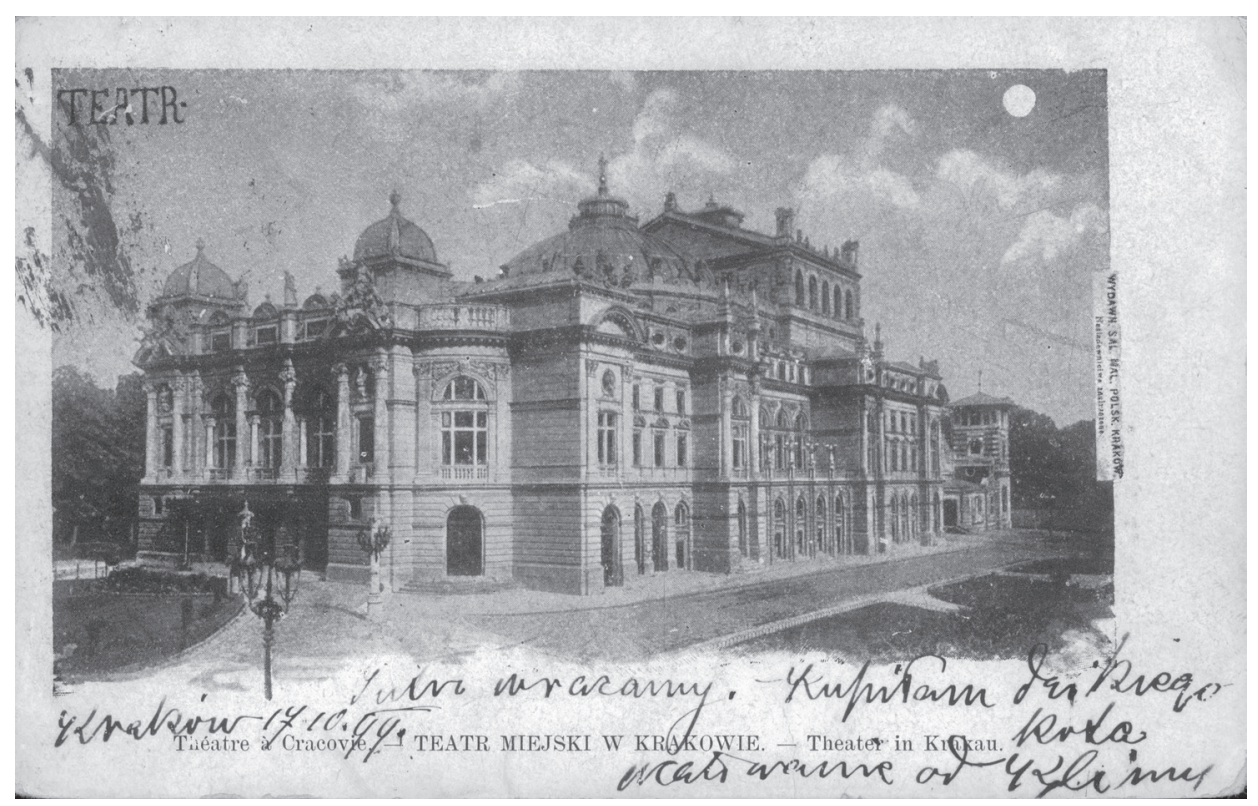

\section{The Polish Theater in Lviv: Three in One}

The situation in Lviv was better, since there was financial and institutional support. Lviv had rich theatrical and operatic traditions. In the times of Wojciech Bogusławski (1795-1799) the opera prospered. Later on, there was a very active theater known as Skarbek's Theater, from the name of a Polish aristocrat, Count Stanisław Skarbek (1780-1848), a great theater lover and a wealthy man. He founded the theater in Lviv, which was active during the years 1842-1899. Count Skarbek was granted imperial privilege to run it, on the condition that he would maintain a German ensemble and put on German productions. The directors of this stage were thus not interested in Polish operas, Stanisław Moniuszko being one of the few exceptions.

The turning point did not come until the period of Galician autonomy. In 1871 the obligation to produce German stagings was revoked. The ambition of the new director, Stanisław Niedzielski, was to create a new ensemble and a national stage. The inauguration of the Polish opera took place on 6 April 1872, with a performance of Moniuszko's Halka. The creation of a national stage caused great 
excitement within the local community and resonated throughout the country. Enthusiasm was enormous, but the beginnings were difficult. ${ }^{9}$

The opera was an integral part of a single theatrical organism, together with the drama and operetta section. All three were housed in one building, on one stage, with one director. The critics described it as a "three-headed hybrid" or a "monster with three heads." ${ }^{10}$ Attempts to separate them were unsuccessful. Managing such an institution was not easy; it required complicated logistics and planning, as well as appropriate financial management. Under successive directors this was achieved with varying degrees of success. The malcontents complained that the opera was too expensive and that it put a strain on the budget for drama and comedy; however, there were also seasons when it was the opera which saved the theater's finances. The directors were under constant control of the critics, the audience, and a parliamentary commission.

The duration of the opera seasons varied, from three to nine months. On average it was three to four months a year. The seasons were short but intense. Usually they would begin with a Polish work, most often Moniuszko's Halka. After the end of the opera season, the drama would come to life. During the summer the opera ensemble would depart for Kraków or Warsaw.

An important moment in the history of the theater was the opening of the new building in 1900. Designed with panache by Zygmunt Gorgolewski and completed to the highest standard, it represented beautiful architecture in an eclectic style with Renaissance elements. The interior was decorated with numerous sculptures and paintings, and the painted curtain was produced by Henryk Siemiradzki. The three-tier auditorium could accommodate 1,100 persons. The opening ceremony took place on 4 October 1900, and among the operas performed was Janek by Władysław Żeleński. The new building allowed actors and singers to grow artistically and enjoy new performance opportunities. At the same time, it played an important social and political role as a place of prestige and power.

The new building transformed the character of the city. In order to be able to construct it on the chosen site, the Pełtev River was diverted underground and canalized along the entire length of today's Prospekt Svobody, Lemberg's equivalent to Wenceslas Square in Prague. This connected the old town and the palatial quarter around the Ossolineum with the Galician parliament building and gave Lemberg a grand boulevard suited to a European metropolis. Furthermore, the Teatr Polski served as a symbol of the Poles' supposed cultural superiority over the Ukrainians, who made up an annually growing proportion of the popu-

9. For a comprehensive history of musical theater in Lviv, see Anna Wypych-Gawrońska, Lwowski teatr operowy i operetkowy w latach 1872-1918 [The Lviv Theater of Opera and Operetta in the years 1872-1918] (Kraków: Universitas, 1999).

10. Ibid., 25. 
lation in Lemberg, and later raised funds to build their own Ruthenian National Theater. ${ }^{11}$

\section{Opera productions under the directorship of Pawlikowski and Heller}

At this time the theater was directed by Tadeusz Pawlikowski (1861-1915), a charismatic figure and visionary theatrical innovator. ${ }^{12}$ Earlier he had been the director of the Municipal Theater in Kraków (1893-1899), then in Lviv (1900-1906) and then again in Kraków (1913-1915). He was passionate about contemporary drama and he promoted young talents. The repertoire at Lviv was very moderne, reacting to new signals flowing from Europe.

The second director, Ludwik Heller (1865-1926), had different priorities and a different vision of theater. He did not have the intuition and sophistication of Pawlikowski, but he was a great aficionado of the opera. This happened partly for family reasons, since his sister and his wife were singers. Under his directorship (1896-1899 and 1906-1918) the opera decidedly moved to the front of the stage. ${ }^{13}$

Pawlikowski and Heller were bitterly opposed to each other. The conflict would intensify during periods of rivalry for the post. The press would become involved in the issue, raising tensions and adding to the heated atmosphere. The climax came when Heller dismissed Konstancja Bednarzewska, a mistress of Pawlikowski. This was fully justified, since she had a romantic affair with an actor, ran off with him and did not return to the theater in time to perform. The scandal was widely reported in the press.

Pawlikowski's contract obliged him to produce at least 30 opera performances per season. However, there were many more; in total, during the six years of his directorship, there were nearly 500 performances. During Heller's second directorship (1906-1918) even more: 837 performances of Polish operas (12 composers, 20 operas) and 1,547 performances of foreign operas (34 composers, 60 operas). ${ }^{14}$ Such an increase in the number of operas was not to everyone's liking. The press claimed that Heller neglected drama, favored opera and promoted his wife, Irena Bohuss-Heller. However, Heller was a good manager; the theater was well pro-

11. Philipp Ther, Center Stage. Operatic Culture and Nation Building in Nineteenth-Century Central Europe, transl. Charlotte Hughes-Kreutzmuller (West Lafayette, Indiana: Purdue University Press, 2014 ), 104.

12. See Jan Michalik, Tadeusz Pawlikowski: legenda, człowiek, teatr [Tadeusz Pawlikowski: legend, man, theater] (Kraków: Muzeum Historyczne Miasta Krakowa, 2015).

13. See Stanisław Hałabuda, "Dyrekcja Ludwika Hellera, lata 1906-1918” [Ludwik Heller's directorship, 1906-1918], in Teatr polski w latach 1890-1918. Zabór austriacki i pruski [Polish theater 1890-1918. Austrian and Prussian partitions] (Warszawa: Państwowe Wydawnictwo Naukowe, 1987).

14. Edward Webersfeld, "Zestawienie ogólne sztuk, oper i operetek wystawianych we Lwowie w czasie 16-letniej dyrekcji Ludwika Hellera" [General overview of dramas, operas, and operettas performed in Lviv during the 16 years of Ludwik Heller's directorship], in Teatr miejski we Lwowie za dyrekcji Ludwika Hellera 1906-1918 [The Municipal Theater in Lviv during the directorship of Ludwik Heller 1906-1918] (Lwów: w Drukarni W. A. Szyjkowskiego, 1917). 
moted and advertised. He invited to Lviv a number of stars, including Marcelina Sembrich-Kochańska and he staged Der Ring des Nibelungen for the first time in a Polish theater.

During Heller's directorship the Lviv Theater saw the performances of 80 operas, a quarter of which were by Polish composers, mainly contemporary ones. During Pawlikowski's directorship 43 operas were performed, including 17 new ones. An important development was the staging of Wagner's works, as well as Puccini's La Bohème and Tosca. There were four Polish premieres: Janek by Władysław Żeleński, Pan Wołodyjowski by Henryk Skirmuntt, Manru by Ignacy Jan Paderewski, and Urwasi by Erazm Dłuski. Stanisław Moniuszko's operas were a permanent feature of the repertoire. ${ }^{15}$

Initially, Pawlikowski took charge of opera himself. He had a musical education and experience as a conductor. His involvement was particularly apparent in the premieres of Żeleński's Janek and Paderewski's Manru. He introduced a number of reforming ideas, giving a new artistic quality to the opera. Pawlikowski was very demanding as a director, expected soloists to act naturally, with no exaggerated gestures or movement. He expanded the orchestra, reorganized the choir, and forbade encores and clapping during the performance. Stage sets, costumes and props had to closely match the historical situation.

\section{The Polish national stage and the European opera canon}

Lviv did really possess a national stage, which was a new phenomenon in Polish lands. Censorship in Galicia was not as strong as in the Russian and Prussian partitions. There was no anxiety of whether national themes might evoke social anxiety. It was in Lviv that the majority of Polish works had their premieres. These included all the operas of Władysław Żeleński: Konrad Wallenrod, Goplana, Janek, and Stara baśń, as well as Zygmunt Noskowski's Livia Quintilla; Ignacy Jan Paderewski’s Manru, Ludomir Różycki’s Bolesław Śmiały, and works by Stanisław Sołtys and Tadeusz Jarecki, also the complete works of Stanisław Moniuszko.

Lviv was thus aiming to promote Polish works, regarding this as a patriotic duty. But this was only a quarter of the full repertoire, and Polish works had relatively short runs. The majority was constituted by the standard range of Italian, French, and German works, well known and popular in Europe. However, this repertoire had its own local characteristics: it mostly consisted of the traditional nineteenth-century canon of works and it was sung in Polish. The sin of singing in foreign languages was forgiven only in case of foreign artists and that not immediately.

15. Jan Michalik, "Teatr Lwowski w latach 1900-106. Dyrekcja Tadeusza Pawlikowskiego" [The Lviv Theater during the years 1900-1906. Tadeusz Pawlikowski's directorship], in Teatr polski w latach 18901918, 258. 
Reviewing the repertoire of the Lviv Theater over a period of 50 years it is apparent that Italian opera was represented more abundantly than any others (Rossini's $I l$ Barbiere di Siviglia, Bellini's Norma, Donizetti's Lucia di Lamermoor). Verdi was in a strong position, a true record holder in respect of the number of works, with Traviata, Aida, and Rigoletto at the top (Plate 2). However, the "late Verdi" did not pass the test; Otello was not to the audiences' taste. Veristic opera did extremely well. Mascagni and Leoncavallo (I Pagliacci was performed nearly every season), but pride of place went to Giacomo Puccini, particularly La Bohème and Tosca.

Plate 2 Playbill of Verdi's Aida at the Lviv Theater, with guest soloists from the Warsaw Opera

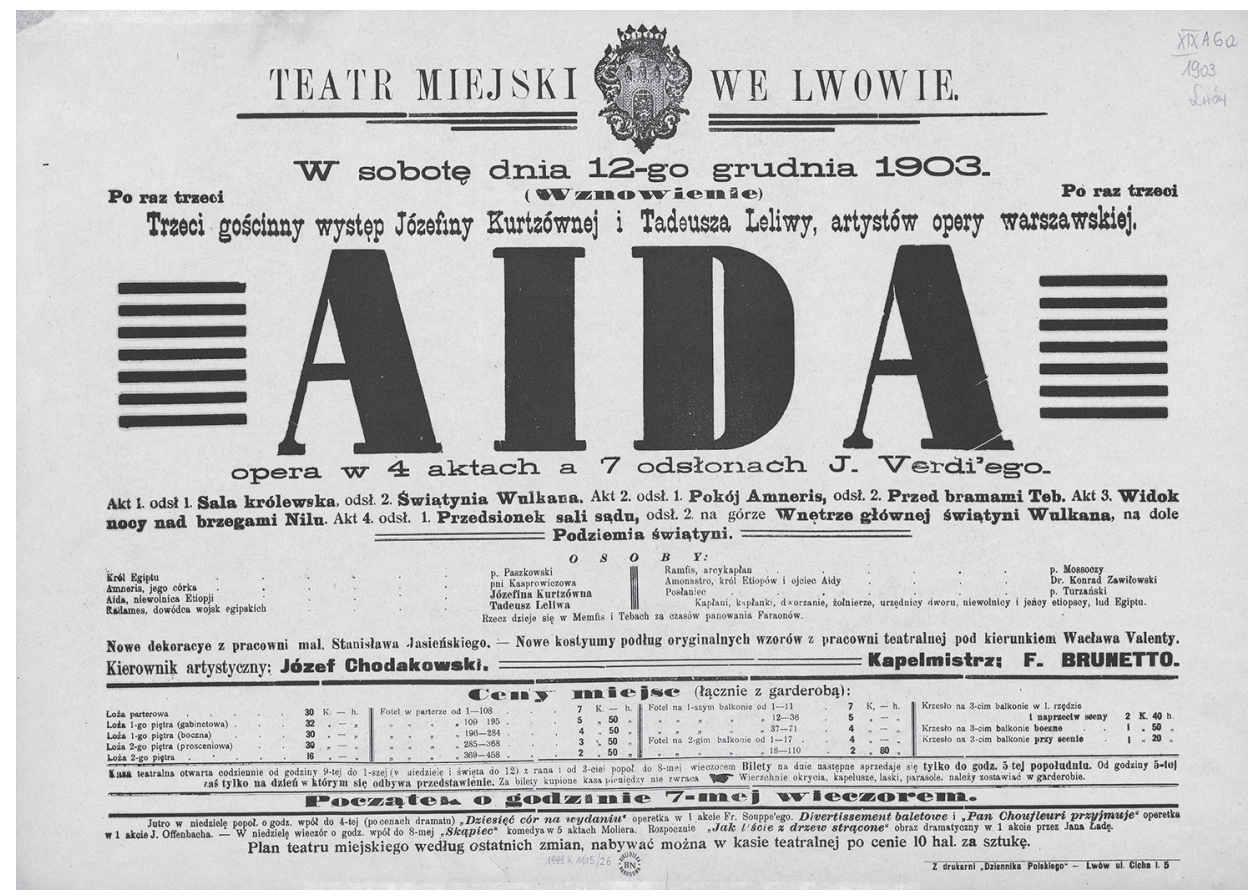

German repertory was mainly represented by Wagner, and also Weber's Freischütz. As for the French, it was Meyerbeer (L'Africaine, Robert le diable), Halévy's La Juive, Gounod's Faust, and Bizet's Carmen. Slavic operas were poorly represented, with the exception of Smetana's Prodaná nevěsta. Very few Russian operas (by Tchaikovsky, Mussorgsky, and Rubinstein) were performed: anti-Russian sentiments were also felt in Galicia. ${ }^{16}$

16. For a detailed analysis of the repertoire see Anna Wypych-Gawrońska, "Repertuar Sceny Operowej" [Repertoire of the opera stage], in Lwowski teatr operowy i operetkowy w latach 1872-1918 [The Lviv Theater of Opera and Operetta during the years 1872-1918] (Kraków: Universitas 1999). 


\section{The Tower of Babel on the Stage}

The strategic aims of the Lviv Theater, clearly defined from the very beginning, were to promote Polish repertoire and Polish language. This was a priority for critics, audiences, and public authorities. As a result, foreign operas were translated and performed in Polish. Some librettos were imported from Warsaw (if they had been staged there earlier), others were translated locally; among others Aureli Urbański, Adolf Kichman, Aleksander Bandrowski, Ludomił German, and many anonymous authors. Concerning the language of the spectacles, after a certain time it came to be accepted that artists from Italy or Germany would not sing in Polish, but in the beginning they were expected to do so. A few brave souls even tried this. Polish artists were expected to use their native language without exception, but this was not obvious to them. In Warsaw they mainly sung in Italian, thus soloists visiting Lviv would want to sing in Italian. But they were heavily criticized both by the press and the audience. Singing in the original language was not welcome.

Some foreign artists, eager to gain favor with the audiences, learned fragments in Polish. One aria or song would be enough to ensure enthusiastic reception (this trick was used very often at benefit concerts). During the performances, they would sing in their native languages, which meant that some spectacles were multilingual. In I Pagliacci (1907/1908) Emma Bel Sorel sang in Italian, Władysław Florjański in Czech (he was not keen on learning the Polish version and knew the Czech one well from his performances in Prague), and the other artists in Polish. In Carmen the soloists would sometimes sing in French and Italian, and the choruses in Polish. Thing became even more interesting when one soloist would sing in different languages. Aleksander Myszuga, a Ukrainian tenor, sang the whole Traviata in Polish, but the duets with Elvira Colonnese in Italian (1893/1894). Mira Heller (Ludwik's sister) sang the scenes with Don José (Carmen) in French, and the rest in Polish (1897/1898). ${ }^{17}$ Such a "tower of Babel" on the stage was criticized by the reviewers, but accepted with understanding by the listeners. Today, this situation is difficult for us to imagine. 


\section{Wagner in Lviv}

At the turn of the centuries, Lviv became an important Wagner center, in comparison with other Polish cities. ${ }^{18}$ The first attempt took place in 1877 with Lohengrin on the stage of Count Skarbek's theater, getting a rather cold reception. Twenty years later, Heller revived Lohengrin which then became a permanent feature in the repertory. It was followed by a whole series of Wagnerian performances. During the same season there was also Tannhäuser, then Rienzi (1899), Der fliegende Holländer (1902), Die Walküre (1903, see Plate 3), Siegfried (1907), Das Rheingold (1908), and Götterdämmerung (1911). The culmination came with the staging of the whole Ring des Nibelungen (1911). ${ }^{19}$

One of the most important Wagner singers was Aleksander Bandrowski, a well-known Heldentenor, performing all over Europe. He had a superb voice which, in combination with an attractive appearance and acting skills, produced

Plate 3 Playbill of Wagner's Die Walküre at the Lviv Theater

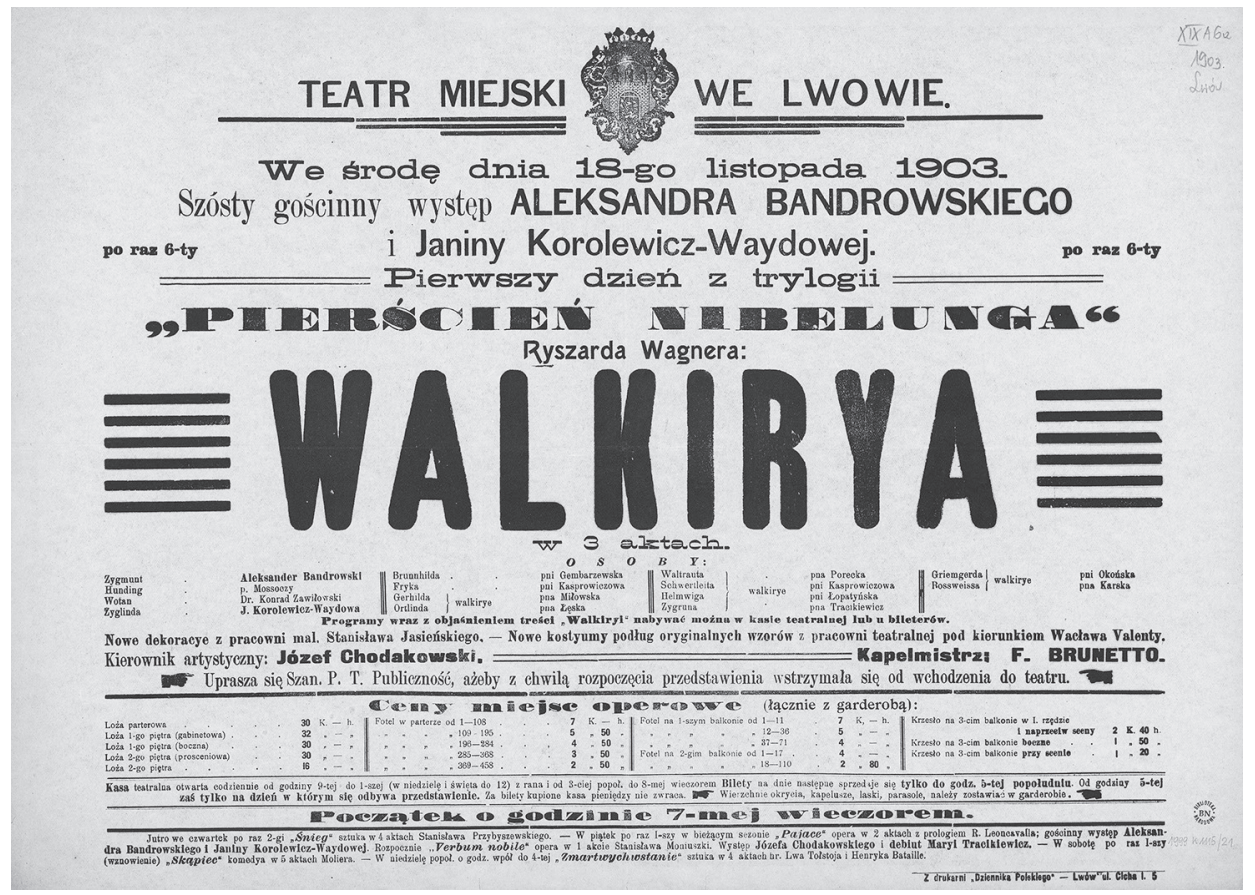

18. Renata Suchowiejko, "Richard Wagners Schaffen im Kontext der polnischen Kultur am Ende des 19. Jahrhunderts. Aufführungen - Diskussionen - Resonanz," in Richard Wagner. Persönlichkeit, Werk und Wirkung, hrsg. Helmut Loos und Katrin Stöck (Leipzig: Sax Verlag, 2013), 417-426.

19. Luba Kyyanovska and Stefania Petruk, "Wagner-Rezeption in der Musikkultur Lembergs (Polen/ Ukraine)," in Richard Wagner. Persönlichkeit, Werk und Wirkung, 427-436. 
an excellent impression. Bandrowski was an enthusiastic promoter of the Wagnerian art: he translated librettos ${ }^{20}$ and published a musical guide to the Ring, modelled on German and French publications. ${ }^{21}$

\section{Kraków and Lviv: the alliance of arts and culture}

Kraków did not have a permanent opera stage. For many years that gap was filled by the artists from Lviv. In 1893, an agreement was signed between both theaters regarding permanent collaboration. Kraków became a "branch" of the Lviv Opera and Operetta Theater.

The season usually lasted two months, between June and August. The visit was well planned and prepared. Guest performances would involve the complete ensemble, with soloists, chorus, orchestra, and administrative staff making the journey (in 1897, for example, 139 people arrived in Kraków). Sets, costumes, and props were also transported, which was a considerable logistic enterprise, involving transport by train, accommodation in Kraków, adapting to the new building, etc. For the time of the visit in Kraków, the ensemble had the whole theater at its disposal, and performances took place almost daily.

The venture was profitable for both sides. Although the guests paid for the opportunity to perform, they also had much to gain. The Lviv Opera was a great attraction for the Cracovians, and the auditorium was always full. This brought an income that made possible to maintain the ensemble in the summer season. However, for the artists it was a heavy burden since they had no holidays. They would finish the season in Lviv, travel to Kraków and return to Lviv for the next season. Artists gave from 50 to 70 performances in Kraków. This included nearly the whole repertoire presented in a given season. Efforts were made to show as many works as possible.

For example, in 1901 the Lviv ensemble presented 23 operas. ${ }^{22}$ The most popular were those by Moniuszko (Halka, Verbum nobile, Straszny dwór). Further staged works included Żeleński's Janek and Paderewski's Manru, both operas having been premiered in Lviv (cf. Plate 4). There were also operas by Verdi (Rigoletto, Traviata), Donizetti (Lucia di Lammermoor), Wagner (Lohengrin), Massenet (Manon), Mascagni (Cavalleria rusticana), and Bizet (Carmen). Operas by Polish composers were also an important element of the program. Lviv pre-

20. Walkiria [Die Walküre; Warszawa 1903], Śpiewacy norymberscy [Die Meistersinger von Nürnberg; Kraków 1903], Złoto Renu [Das Rheingold; Kraków 1908], and Zmierzch bogów [Götterdämmerung; Kraków 1910].

21. Aleksander Bandrowski, Rozbiór tematyczny Trylogii Pierścień Nibelunga [Thematic guide through Wagner's trilogy Der Ring des Nibelungen], (Lviv: 1907).

22. Their performances were widely commented in the local press, especially in the dailies Czas and Nowa Reforma. 
Plate 4 Playbill of Ignacy Jan Paderewski’s Manru, performed at the Kraków Theater by the Lviv ensemble

\section{W Początek o godzinie $71 / 2$.}

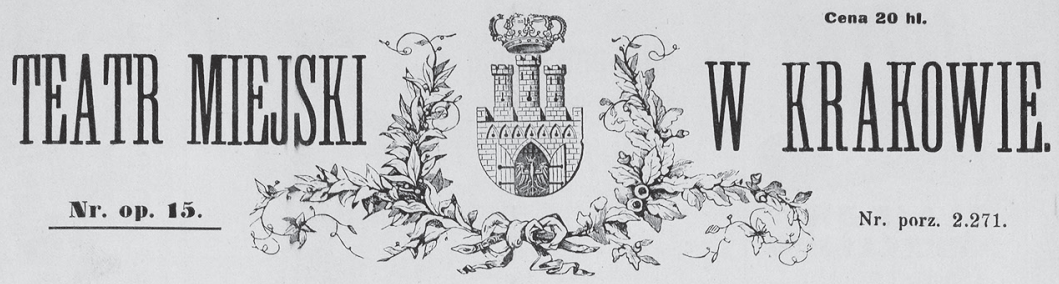

\section{OPERA POLSKA TEATRU MIEJSKIEEO ze LWOWA w KRAKOWIE.}

We Środe dnia 24 Lipca 1901 roku

GOSCINNY WYSTEP

ALEKSANDRA BANDROWSKIEGO
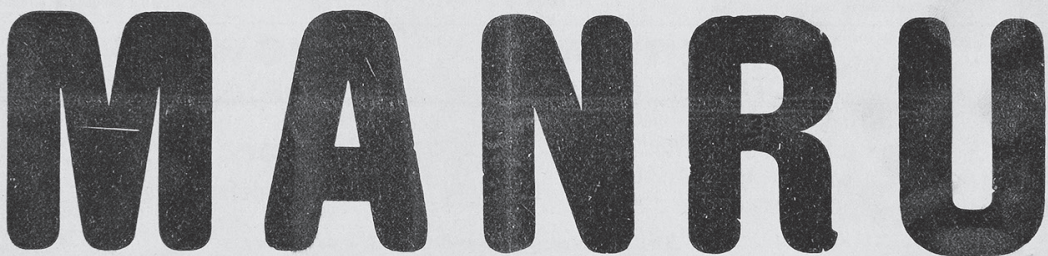

Opera w 3 aktach, slowa Alfreda Nossiga; muz. I. J. Paderewskiego.

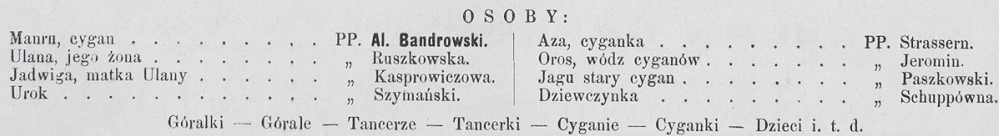

Goralki - Gorale - Tancerze - Tancerki - Cyganie - Cyganki - Dzieci i. t. d.

Rzecz dzieje siẹ w akcie I. w Tatrach, w okolicy Zakopanego, w akcie II. przed chatą i kużnią Manru, w akcie III. przy „Morskiem Oku“.

Tańce: w akcie I. "Taniec góralski“ nkładu p. Bergera nadwornej opery w Dreźnie; wykonają p. Staszko, p. Żymirski i Corps de ballet.

\section{Kapelmistrz: I. Spetrino.}

NOWE DEKORACYE NOWE KOSTYUMY

z pracowni malarskiej St. Jasienskicgo. z pracowni teatralnej pod kierunkiem J. Balińskiego. Po drugim akcie dłuksza przerwa.

We Poczatek o godzinie $7 / 2$ - konice o godzinie 11.

Księgarnia, skład nut, wypożyczalnia nut i Książek L. 'Zwolińskiego i Spdilki w Krakowie, ul. Grodzka 40 Poleca:

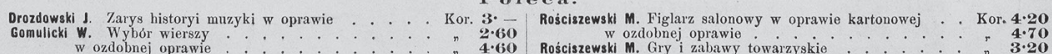

Matka Polka. Dramat

liedziałkowski K. Nie tedy droga, szanowne panie

Przybyszewski st. Na drogach diszz:

Rościszewski M. Figlarz salonowy broos.

Wo ozdobnej oprawie
Ruskin J. Królowa posietrza.

2.(60) Ruskin J. Królowa posietra.

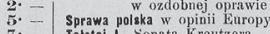

We Czwartek „Traviata“, opera w ezterech aktach Józefa Verdi'ego (po cenach znizonych).

W Drukarni ,Czasu“ w Krakowie.

Nakl \& dem Dyrekcyi Teatru Miejskiego. 
mieres almost always had their re-runs in Kraków, for example Konrad Wallenrod by Żeleński. In the case of this composer a reverse situation also took place, since his Goplana was first premiered in Kraków and then in Lviv. This total symbiosis of the theaters satisfied immediate needs, but it also paralyzed attempts to create a local opera.

Sometimes the Lviv ensemble could not come to Kraków because they gave guest performances in other cities. On such occasions artists were brought from Italy, e.g. in the summer of 1900/1901. The Italians presented 37 spectacles, including Italian works by Bellini, Donizetti, Rossini, Verdi, and Puccini, and French works by Gounod, Massenet, and Bizet. The Cracovians saw for the first time the "old" Bellini, I puritani, but also the "new" Puccini, La Bohème (four years after its premiere in Turin). The Italian singers came to Lviv on different occasions taking part in opera performances and giving concerts. ${ }^{23}$

\section{Austrian military bands in Kraków}

When Italians came to Kraków, organizing the season became more complex, especially as regards the orchestra. It had to be provided locally. However, Kraków did not have a permanent symphony orchestra. The string section was well formed, but there was a shortage of wind instruments. In those cases help came from the Austrian military bands. Kraków was located on the far edge of Austria-Hungary, in close neighborhood of Prussia and Russia. So, it was a location of a great military and strategic importance.

As we can read in the 1905 Baedeker Guide for travelers, the city was advertised as a place being rich in cultural heritage and having complicated history with its royal past and military present:

Cracow, Pol. Kraków, Ger. Krakau, situated in an extensive plain at the confluence of the Rudawa and the Vistula Rivers, once (1320-1610) the capital of Poland, is now an Austrian fortress of the first class, with a population of 91300 (one-fourth Jews), including a garrison of 6000 men. The churches and towers, the lofty Schloss, and the pleasant promenades planted with trees (Planty), on the site of the old fortifications, round the inner town, produce an imposing effect. [...] The favourable position of the town, its adhesion to the Hanseatic League, and the foundations of the University by Casimir the Great in 1364, all contributed to the progress of Cracow, which reached the

23. Kostiantyn Batsak, Італійські оперні виконавці на театральних та концертних сценах Львова (остання третина XIX - початок XX століть) [Italian opera performers on Lviv theatrical and concert stages (the last third of the nineteenth century - the beginning of the twentieth century)], Visnyk [Herald] of the Lviv University (= Art Studies 16). 
zenith of its prosperity in the 16th century. The period of decline began with the transference of the royal residence to Warsaw in 1610 and with the warlike commotions of the 17th century, but until 1734 the Polish kings continued to be crowned and buried at Cracow. In the final partition of Poland (1795) Cracow fell to Austria. In 1815 it became the capital of a small independent state, but it was again annexed by Austria after the insurrection of 1846. Cracow, however, has never lost its thoroughly Polish character. ${ }^{24}$

Actually, there were much more Austrian soldiers, including all the crews of the main garrison as well as those deployed in the surroundings. As stated by the historians, ca. 12,000 soldiers were stationed in Kraków around $1900^{25}$ and this fact set a stamp on the cultural profile of the town. Military bands came to Kraków together with the Austrian army. At that time there were four of them, the 13th, 20th, 56th, and the 100th Infantry Regiments. They participated intensively in the musical life of the city, not only in the military events, but also in the municipal, religious, social and charity celebrations. A certain portion of repertoire, particularly symphonic works and oratorios could not have been performed at all without the engagement of the military bands. They featured, on a regular basis, in opera performances and concerts organized by the Musical Society. Supported by local artists, they performed also in churches where they played oratorios or certain parts of symphonic works. Finally, they were the main musical highlights of dancing parties, parades, banquets, celebrations, and festivities. The spectrum of areas shaped by the musical activity of the military bands was really vast. Local newspapers Czas and Nowa Reforma reported a number of events highlighted by the bands.

Particularly active were the military bands of the 56th and 13th Infantry Regiments. The first of them performed, on a regular basis, during concerts held by the Musical Society in the "Saski" Hotel, the Hall of the "Sokół" Gymnastic Society and in the concert hall at 3 Szczepański Square, whilst the military band of the 13th Infantry Regiment was privileged to play in the Municipal Theater Hall. The active presence of these orchestras was, to a considerable degree, owed to Max Heyda and Johann Nepomuk Hock, whose recognition and respect in the local society had a decisive meaning. Both bandmasters undertook various initiatives and became genuine animators of the musical life. Hock, an excellent conductor and violinist born in Budapest in 1850, played an exceptional role (Plate 5). He came to Kraków in 1882 and remained there for 30 years. He was a Hungarian by

24. Austria-Hungary, including Dalmatia and Bosnia. Handbook for travellers by Karl Baedeker with 35 maps and 44 plans (Leipzig: Karl Baedeker Publisher, 101905), 277.

25. See Michał Baczkowski, Pod czarno-żółtymi sztandarami. Galicja i jej mieszkańcy wobec austro-węgierskich struktur militarnych 1868-1914 [Under the black and yellow flag: Galicia and its inhabitants' approach to the Austro-Hungarian military structures 1868-1914], (Kraków: Towarszystwo Wydawnicze Historia Iagellonica, 2003). 
Plate 5 Poster of Rossini's Il Barviere di Siviglia in the Kraków Theater, performed by Italian artists and conducted by Johann Nepomuk Hock

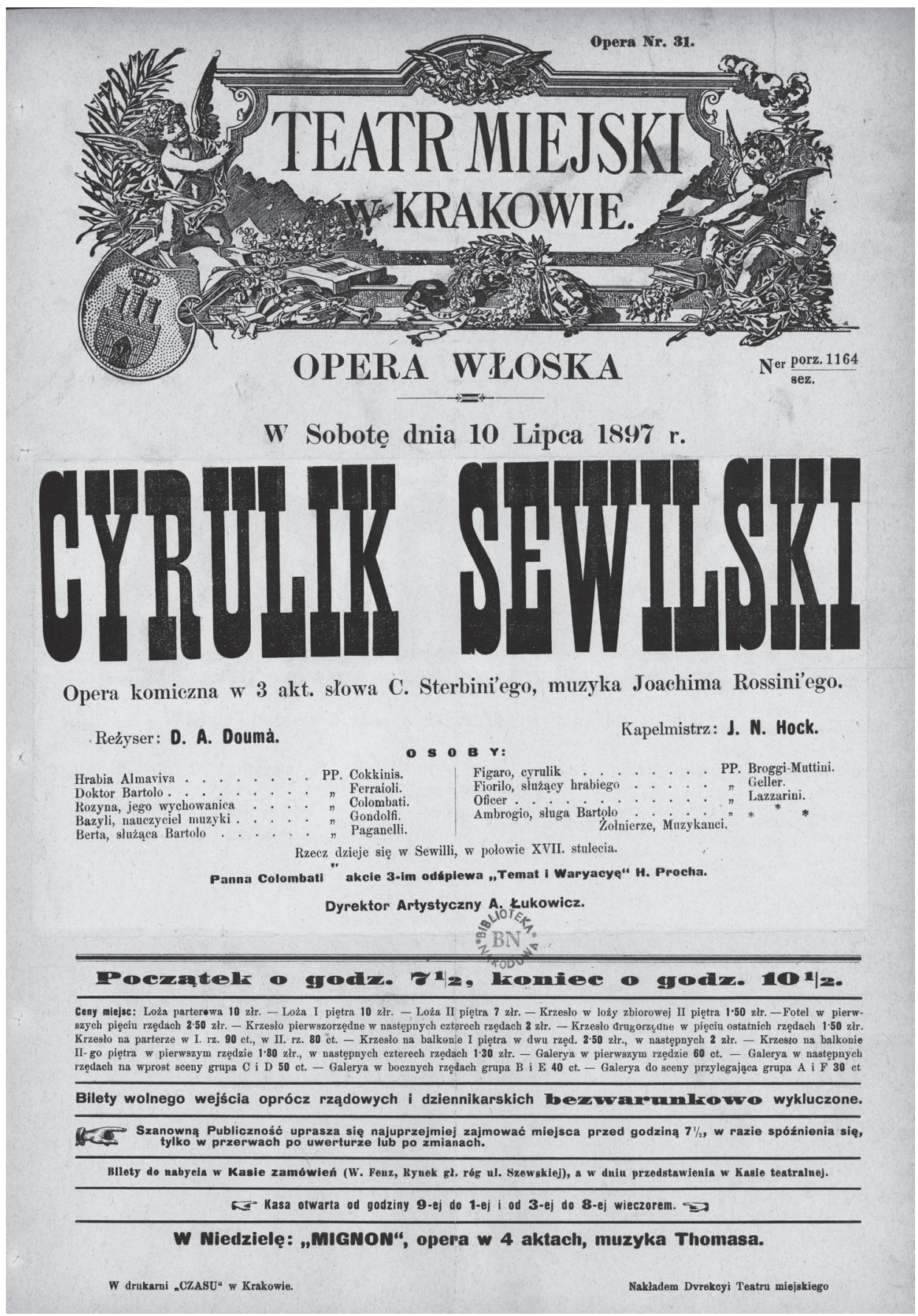


birth and an Austrian Kapellmeister by profession, attached very strongly to his adopted homeland, Poland. Hock's orchestra was of fundamental importance for the opera in Kraków, and also outside the theater.

\section{"Disputed territories and shared past" in music historiography?}

The First World War fundamentally changed the political map of Europe. Poland regained the independence in 1918, but it did not bring immediately stability and peace. The war with Soviet Russia lasted until 1921, when the treaty of Riga was signed and the Polish-Soviet borders were established. Lviv was included within the boundaries of the Second Polish Republic until 1939. After the Second World War the city was absorbed into the Soviet Union and found itself on the other side of the Polish border.

Boundaries would shift, the rulers would change, and nations would fight for their identity. As it happened, the victory of one nation was a tragedy for the other. In the borderland areas, national conflicts and territorial overlaps were something natural. ${ }^{26}$ At the same time, people created a shared history, and moved around the same cultural space. How can this be perceived today, while we are creating historical narratives? National mapping of the history of music continues to be present in musicology. The question of "inclusion" vs. "exclusion" of a given composer, style or repertoire from the historical narratives is still current.

However, when the national perspective is adopted, only one thread is pulled out of the dense tangle of overlapping national histories. And these threads often differ from each other, depending on who does the pulling. Our visions of the past are different: everyone has one's own history, worships one's own heroes, and creates one's own canon. And consequently new boundaries arise. Can they be broken through in music historiography, overcoming this kind of separatism and creating a new approach to the musical past with respect to its transnational nature? Such approach seems particularly vital in relation to Eastern Europe where the cultural heritage is a result of overlapping national histories. Therefore, historic narration should cover various aspects of history, including both "disputed territories" and "shared pasts."

26. See Disputed Territories and Shared Pasts. Overlapping National Histories in Modern Europe, eds. Tibor Frank and Frank Hadler (Basingstoke: Palgrave Macmillan, 2015). 
